\title{
マルチストロボ装置を応用した下顎運動の研究
}

\author{
一ア音発音時の下顎頭について一
}

\section{長島 信也}

\author{
A Study of the Mandibular Movement \\ with Multiple Stroboscope Apparatus \\ - The Mandibular Condyle Movement during \\ the $[\mathrm{a}:]$ Sound was Pronounced-
}

Shinya Nagashima

\section{第 1 章 緒 言}

下顎運動の研究は, 1889 年 Luce ${ }^{1)}$ が初めて生体の運 動を測定して以来, 多くの報告がなされている. これら の研究の多くは, 矢状面内における下顎の習慣的開閉運 動, 咀嚼運動あるいは限界運動時の切歯点および下顎頭 部の対応する運動様相をそれぞれの目的により種々な計 測法によって解析報告 ${ }^{2299}$ したものである. そして下顎 頭部の運動は, 移動と回転という2つの運動要素に分け られる ${ }^{30,31)}$ こど明らかとなっている. しかし，この2 つの要素が生理的な下顎運動時にどのように組合さって 発現しているかという研究は少ない. また開口量との関 連や側方運動と関連させた砸究 ${ }^{32 ~ 34)}$ は散見されるのみ である.

生理的な機能運動時, 特に発音時の下顎運動について みると, 切歯点に関しては $[\mathrm{s}][\mathrm{f}][\mathrm{m}]$ 音発音時の下顎 切歯点の位置や前歯部の垂直 ·水平被蓋度との関連およ び咬頭嵌合位（中心咬合位）や中心位における咬合高径 との関連については関心が持たれ詳細に研究されている が12,22,23,35 42), 発音時の下顎頭部の運動様相について詳 細な検討を加えている研究はほとんど ${ }^{12)}$ 見当らない. し かし，このことについて検討することは，䪽口腔系機能

日本大学大学院歯学研究科歯科臨床系専攻 (指遒 : 五十嵐孝義 教授, 中澤 靖教授)

Nihon University Graduate School of Dentistry at Tokyo (Major in Prosthodontics), (Director: Prof. Takayoshi Igarashi, Prof. Yasushi Nakazawa)

昭和 59 年 1 月 17 日受付
異常者の鑑別診断上，非常に益するところ大であると考 えられる.

そこで著者は発音時の下顎頭部の運動のうち, 咬合関 係や前苗部の垂直・水平被蓋度の影響をほとんど受け ず41), 開口を伴って発音する日本語母音のア音発音時の 下頡頭部の運動に注目し、マルチストロボ装置を応用し た写真撮影法により発音時の下顎頭部の運動を記録解析 し, 生理機能的発音時の下顎頭部の移動と回転の様相を 時間的対応をもって検討した。

\section{第 2 章 実験方法}

\section{1. 被験者}

被験者は日常時の談話に異常が認められず, 最大咬頭 欮合位（以下 C.O. と略す）が明確でしかもア音発音時 に側方偏位の少ない健常有歯顎者の, 本学学生 7 名を選 んだ.

\section{2. 計測装置および計測方法}

計測装置ならびに計測方法は第 1 報 $^{43)}$ に準じた。 以下 その概要を記する.

1）マルチストロボ装置

マルチストロボ装置の本体には，菅原研究所製ストロ ボスコープ MS-230 およびランプハウス SL-230を使用 した. 本装監は閃光周波数を無段階に選択することがで きるが，本研究においては 5,000 r.p.m. 寸なわち 0.012 秒間隔にて閃光時間 $1.6 \times 10^{-6}$ 秒で繰返し閃光させ標識 点として，連続瞬間写真を得ることができる. 


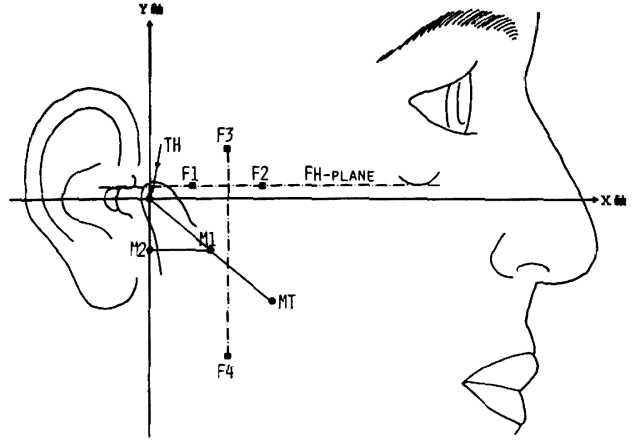

図 1 頭部之標識点, 座標軸の関倸

また，発音位とそれに対応する下頡頭部の運動の様相 を明らかにするため，発音時の位置を確認することが必 要となる. そこで発音と同時にもう1つのストロボスコ ープを作動させるため，発声音をプリモ社製コンデンサ ーマイク EM-4000（感度 $-68 \mathrm{~dB} \pm 3 \mathrm{~dB}$ ) により集音 すると同時に電気信号に変えここの信号によりクセノン 管を自動発光させるスイッチ装置を開発し使用した。こ れによりクセノン管は発音と同時に発光することになる (以後, この位置をア音開始位と略す).

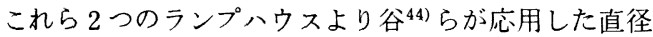
$0.2 \mathrm{~mm}$ の光フィイバーをとおし， 8 つの点光源走標識 点とした.

\section{2）頭部の固定および標識点の設定（図 1）}

被験者を歯科用治療椅子に背すじを直ぐにした姿勢で 座らせた，頭部を左右の耳軸と安頭台にて固定し，標識 点固定用上弓は $\mathrm{FH}$ 平面に一致するように耳軸とノー ズピースにより固定した.この上弓上で耳軸より前方 $20 \mathrm{~mm}$ の位置に F1 をさらにその前方 $20 \mathrm{~mm}$ に F2 を 標識点として設定した. 下号はレジン製シーネを介して 下顎歯列に固定した. あらかじめ Hinge-axis をもとめ, この位置に標識点 THを下顎頭の位置として設定した. さらに下䫂の移動および回転の関倸を知るため, TH よ り前方 $35 \mathrm{~mm}$ 下方 $30 \mathrm{~mm}$ の位置に標識点 $\mathrm{MT}$ を設定 した. この上弓と下弓上の 4 標識点, F1, F2, TH, MT には, ストロボスコープに内蔵の発振回路により連続発 光するランプハウスから光ファイバーにより光を導びい た. すなわち 0.012 秒ごとの繰返し閃光を発光する.

また，発音開始を示す標識点として，さきに上弓上に 設定した標識点 F1, F2 の中間点をとおり FH 平面に直 行する線上でそれぞれ $\mathrm{FH}$ 平面の上方 $10 \mathrm{~mm}$ と下方 50 $\mathrm{mm}$ の位置に標識点 F3, F4 を, 下弓上の標識点 $\mathrm{TH}$, $\mathrm{MT}$ の中間点に標識点 $\mathrm{M} 1$ を, FH 平面に垂直で THを
とおる線上で $\mathrm{FH}$ 平面に平行かつ M1 をと沶る線の交 点に標識点 M2 をそれぞれ設定した. この F3，F4，M1， M2 の 4 点には，発音と同時に発光するランプハウスよ りの光を導びいた.

3）撮影装置

撮影には, 日本光学社製 F2 カメラにマイクロニッコ ール 105 mm F-4 レンズを取り付け，左右の耳軸にレン ズの光軸を一致させ，標識点より $750 \mathrm{~mm}$ 離れた位置よ り発音時の下頡運動を撮影した. フィルムはコダック社 製 Try-X (ASA 400，27 DIN) を使用した.

4） ストリーク装置

連続瞬間写真では 1 枚のフィルム上に受重撮影する と, 移動量が少ない場合や後戻りがあると像が重なり, その判別が困難になる、これを防ぐため約 $1 \mathrm{~m} / \mathrm{sec} の$ 速度でフィルムを流す菅原研究所製ストリーク 3 型 C-0315 高速ュニットを使用した.

5）撮影方法

撮影に先だち被騃者の頭部を固定し上・下马を取り付 けた状態で生理的に楽な発音で〔a：〕を十分発音練習さ せた．発音確認のためには、菊水電子社製オシロスコー プ5520 型を使用した.

その後暗室内で C.O. にてストロボを発光させ，各標 識点の関係をフィルム上に記録した後、シャッターを開 放にしストリーク装置を作動させ，ア音発音時の下顎運 動を撮影した. なお運動の出発点は C.O.とし，また運 動の終了はア音発音を続けられる位置（以後, 停止位と 略す）とした。

6) 解析装置について

前記装置により 800 標識点はそれぞれ点としてフィ ルム上に連続撮影記録される。この点を，ナック社製ス ポーティアス Model 100 によって読み取り, ア音発音 時の下䫟頭運動解析を行った。

7）座標軸の決定と移動量，回転揑および所要時間の 算出法

下顎頭部標識点 TH の移動を求めるための座標は C. O. の標識点 $\mathrm{TH}$ の位置を原点として, x 軸は $\mathrm{FH}$ 平面に 相当する標識点 F1，F2をとおる線に平行な軸， $\mathrm{y}$ 軸は $\mathrm{x}$ 軸に垂直でかつ標識点 TH をとおる軸とした（図 1).

移動量は C.O.の標識点 TH から 0.012 秒ごとのそれ ぞれの標識点 TH の位置の間を直線で結び，その距離よ り求めた．すなわち，C.O.を $T_{1}, 0.012$ 秒後の位置を $\mathrm{T}_{2}, \mathrm{~T}_{1} \mathrm{~T}_{2}$ 間の淔線距雖を $\mathrm{d}_{1}$, さらに 0.012 秒後の位置 を $\mathrm{T}_{\mathrm{j}}, \mathrm{T}_{2} \mathrm{~T}_{3}$ 閒の值線距離を $\mathrm{d}_{2}$ とすると, $\mathrm{Tn}$ までの総 移動量は $\mathrm{d}_{1}+\mathrm{d}_{2}+\cdots \cdots+\mathrm{d}_{\mathrm{n}-1}$ となる. 
表 1 被験者 1 における, 下頭頭の移動, 回転および所要時間（S：開始位）

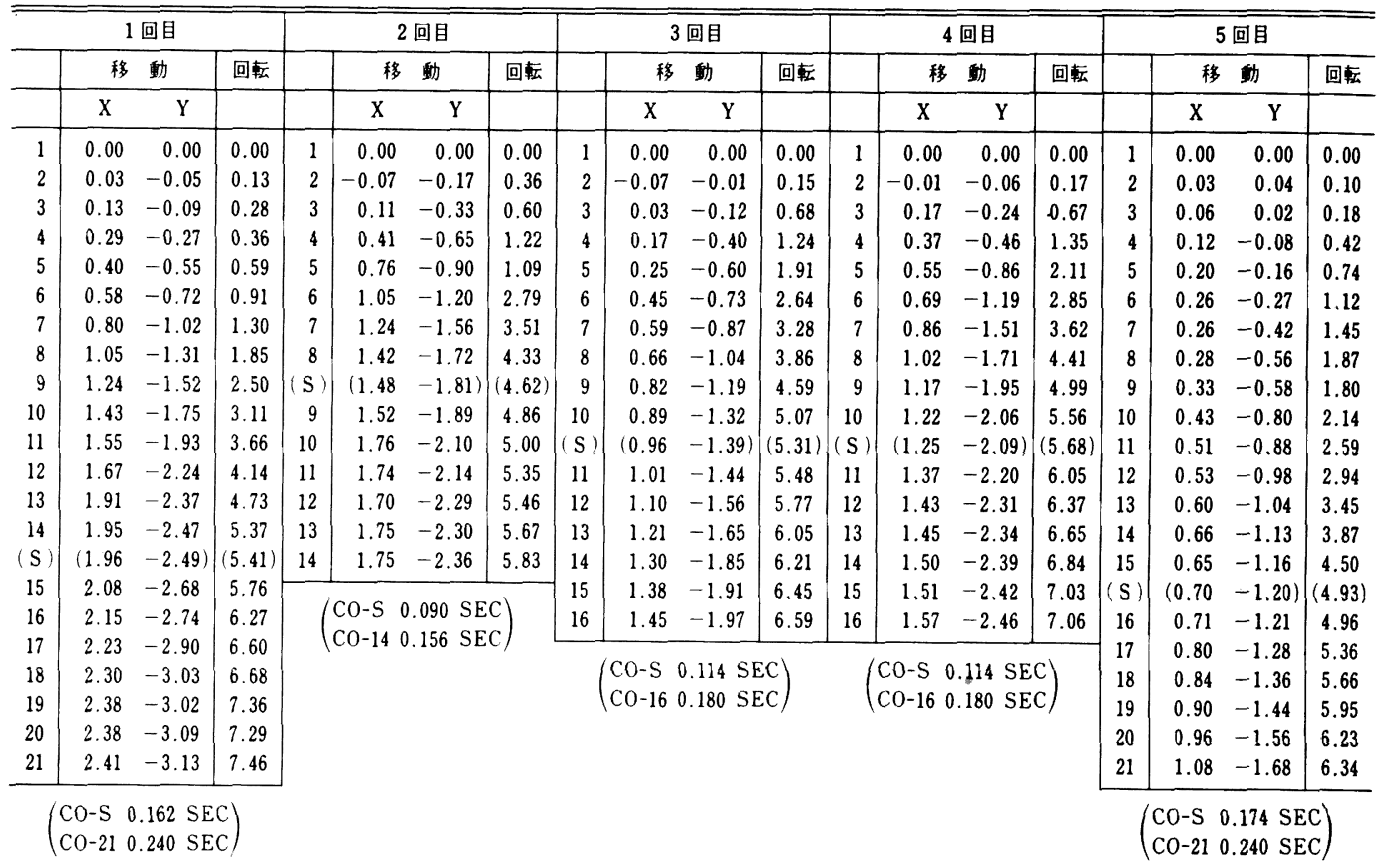

表 2 被験者 2 における, 下䫟頭の移動, 回転抢上び所要時間 ( $\mathrm{S}$ ：開始位)

単位: 移動：mm 回転: 度

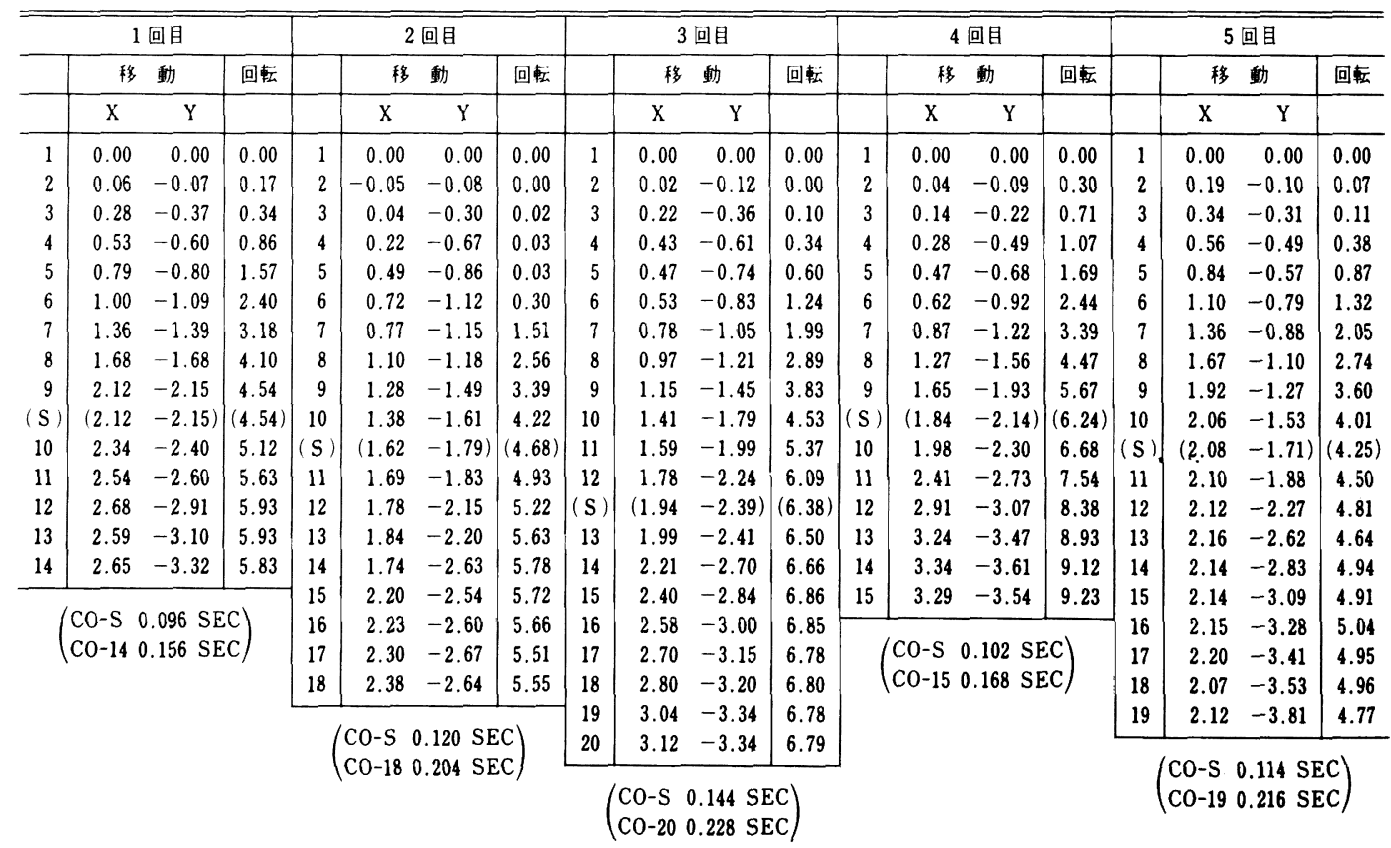


表 3 被験者 3 における，下顎頭の移動，回転および所要時間（S：開始位）

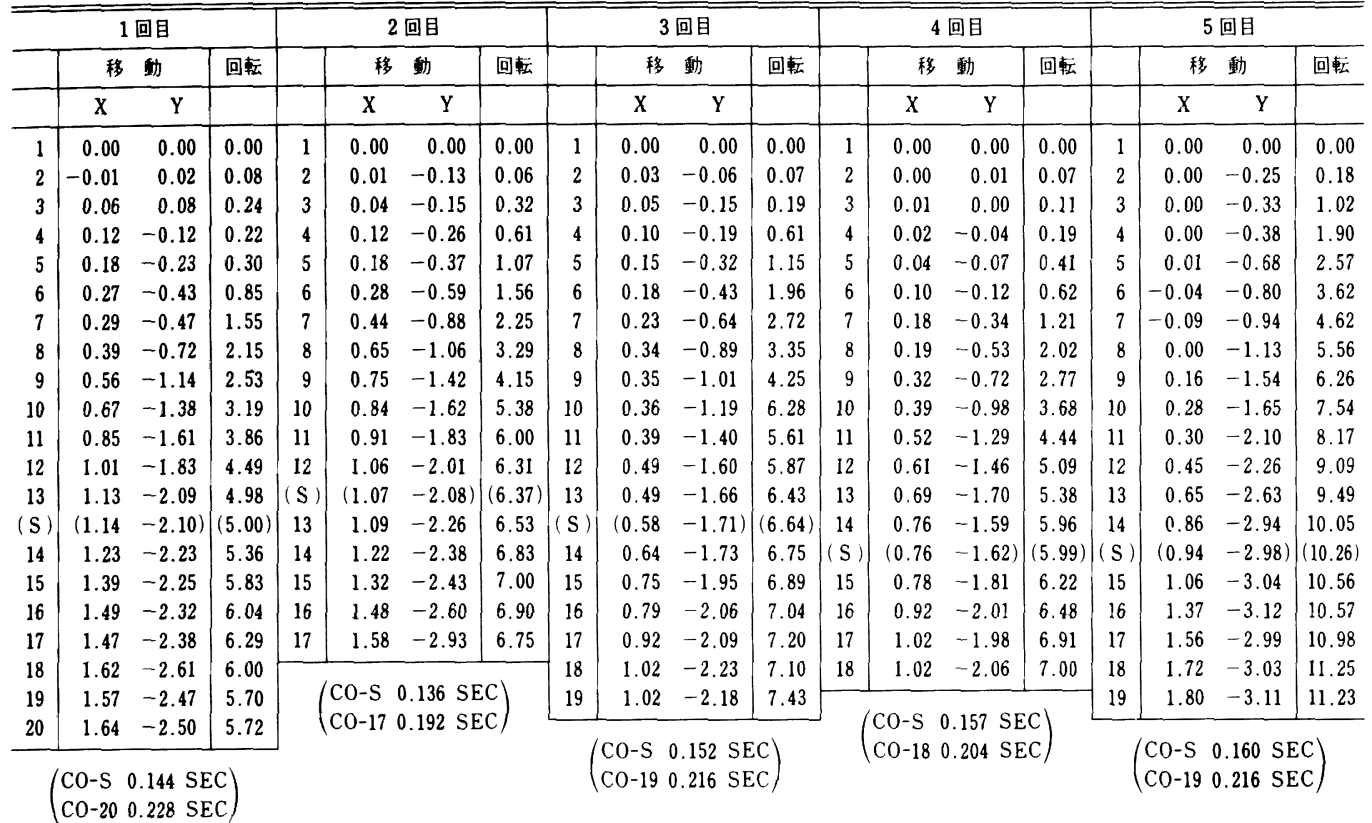

表 4 被験者 4 における, 下顎頭の移動，回転掞よび所要時間（S：開始位）

単位：移動：mm

回軽: 度

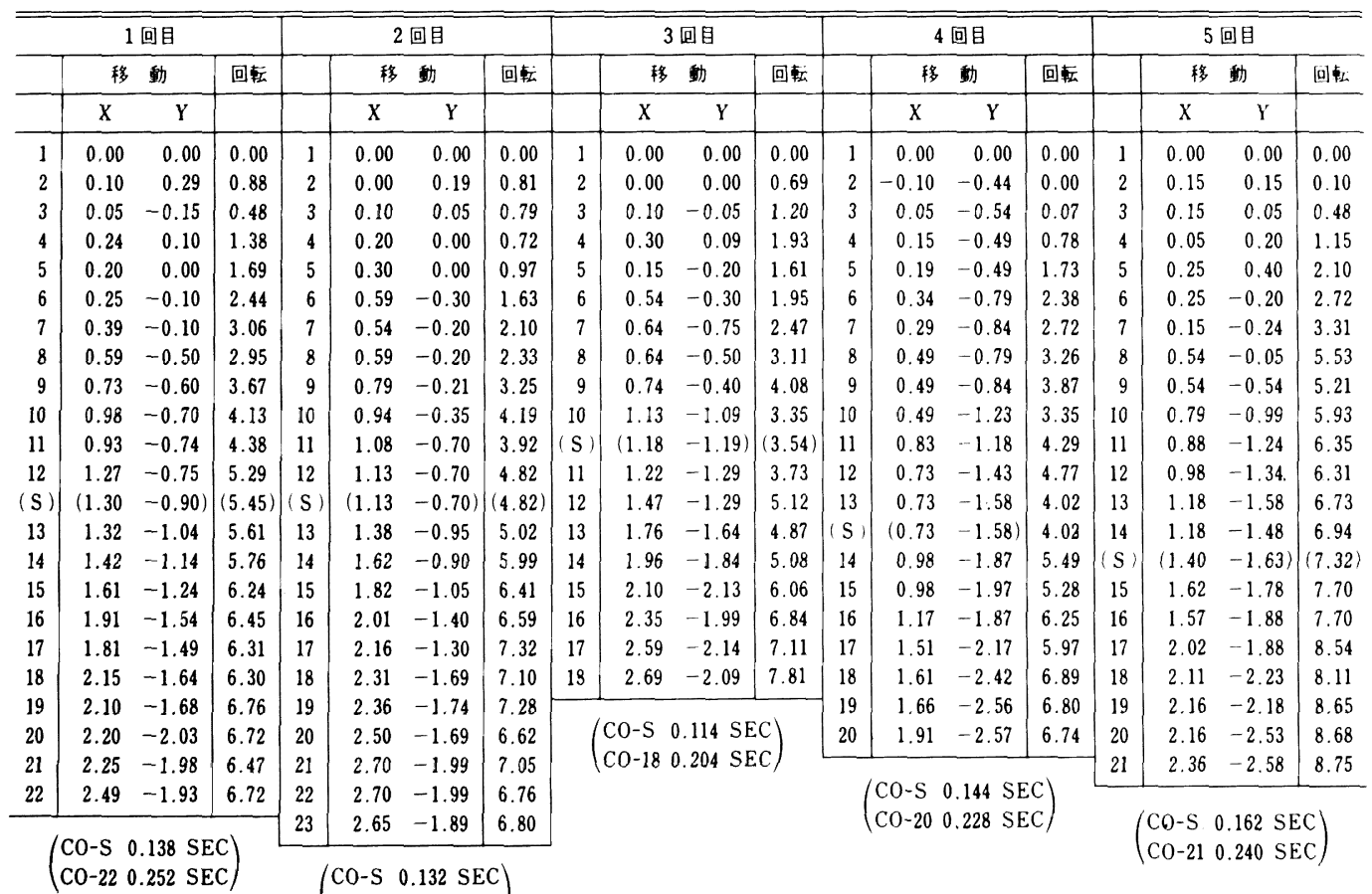


表 5 被験者 5 における，下枵頭の移動，回転および所要時間（S：開始位）

\begin{tabular}{|c|c|c|c|c|c|c|c|c|c|c|c|c|c|c|c|c|c|c|c|}
\hline \multicolumn{4}{|c|}{1 回目 } & \multicolumn{4}{|c|}{2 回目 } & \multicolumn{4}{|c|}{3 回目 } & \multicolumn{4}{|c|}{4 回目 } & \multicolumn{4}{|c|}{5 回目 } \\
\hline & \multicolumn{2}{|c|}{ 移 動 } & \multirow[t]{2}{*}{ 回転 } & & \multicolumn{2}{|c|}{ 移 動 } & \multirow[t]{2}{*}{ 回転 } & & \multicolumn{2}{|c|}{ 移 動 } & \multirow[t]{2}{*}{ 回転 } & & \multicolumn{2}{|c|}{ 移 動 } & \multirow[t]{2}{*}{ 回転 } & & \multicolumn{2}{|c|}{ 移 功 } & \multirow[t]{2}{*}{ 回䡚 } \\
\hline & $\mathrm{X}$ & $\mathrm{Y}$ & & & $\mathrm{X}$ & $\mathrm{Y}$ & & & $\mathrm{X}$ & Y & & & $\mathrm{X}$ & $\mathrm{Y}$ & & & $\mathrm{X}$ & $\mathrm{Y}$ & \\
\hline 1 & 0.00 & 0.00 & 0.00 & 1 & 0.00 & 0.00 & 0.00 & 1 & 0.00 & 0.00 & 0.00 & 1 & 0.00 & 0.00 & 0.00 & 1 & 0.00 & 0.00 & 0.00 \\
\hline 2 & 0.05 & -0.10 & 0.00 & 2 & 0.10 & 0.15 & 0.96 & 2 & 0.39 & 0.09 & 0.79 & 2 & 0.05 & 0.19 & 0.95 & 2 & 0.44 & -0.10 & 0.50 \\
\hline 3 & 0.34 & 0.04 & 0.24 & 3 & 0.15 & -0.05 & 0.63 & 3 & 0.77 & -0.15 & 0.09 & 3 & 0.48 & -0.05 & 1.07 & 3 & 0.44 & -0.05 & 0.02 \\
\hline 4 & 0.44 & -0.15 & 0.31 & 4 & 0.25 & -0.09 & 0.01 & 4 & 1.01 & -0.20 & 1.44 & 4 & 0.66 & -0.34 & 1.00 & 4 & 0.53 & -0.15 & 0.03 \\
\hline 5 & 0.78 & -0.30 & 0.21 & 5 & 0.34 & -0.09 & 0.33 & 5 & 1.63 & -0.30 & 2.94 & 5 & 1.28 & -0.44 & 1.92 & 5 & 0.58 & -0.05 & 0.39 \\
\hline 6 & 1.07 & -0.65 & 0.93 & 6 & 0.49 & -0.29 & 0.62 & 6 & 1.87 & -0.83 & 3.10 & 6 & 1.70 & -0.91 & 2.52 & 6 & 0.87 & -0.05 & 0.96 \\
\hline 7 & 1.45 & -1.14 & 1.17 & 7 & 0.73 & -0.19 & 0.72 & 7 & 2.11 & -0.97 & 4.37 & 7 & 2.22 & -1.39 & 3.42 & 7 & 1.30 & -0.44 & 0.93 \\
\hline 8 & 2.18 & -1.39 & 2.82 & 8 & 0.88 & -0.24 & 1.29 & 8 & 2.54 & -1.07 & 5.76 & 8 & 2.70 & -1.39 & 5.32 & 8 & 1.69 & -0.59 & 1.79 \\
\hline 9 & 2.57 & -1.73 & 4.29 & 9 & 1.07 & -0.53 & 1.73 & (S) & $(2.80$ & $-1.41)$ & $(6.33)$ & 9 & 3.17 & -1.77 & 5.91 & 9 & 2.41 & -1.22 & 1.89 \\
\hline 10 & 3.01 & -2.02 & 4.61 & 10 & 1.31 & -0.92 & 1.82 & 9 & 3.06 & -1.74 & 6.90 & 10 & 3.64 & -2.01 & 6.69 & 10 & 3.08 & -1.27 & 4.21 \\
\hline 11 & 3.44 & -2.47 & 5.42 & 11 & 1.46 & -0.78 & 2.11 & 10 & 3.69 & -2.08 & 7.42 & 11 & 4.40 & -2.49 & 7.22 & 11 & 3.51 & -1.66 & 5.59 \\
\hline 12 & 4.03 & -2.62 & 6.01 & 12 & 1.65 & -1.02 & 1.77 & 11 & 4.31 & -2.56 & 8.11 & (S ) & (4.71 & $-2.71)$ & $(8.19)$ & 12 & 4.28 & -2.39 & 5.44 \\
\hline (S) & $(4.18$ & -2.84 & $(6.45)$ & 13 & 1.89 & -1.12 & 2.62 & 12 & 4.93 & -2.71 & 9.63 & 12 & 5.01 & -2.92 & 9.16 & $(\mathrm{~S})$ & $(4.59$ & $-2.49)$ & $(5.94)$ \\
\hline 13 & 4.32 & -3.06 & 6.88 & 14 & 2.23 & -1.16 & 2.95 & 13 & 5.60 & -2.86 & 10.74 & 13 & 5.72 & -3.49 & 9.14 & 13 & 4.90 & -2.59 & 6.45 \\
\hline 14 & 4.66 & -3.21 & 7.54 & 15 & 2.42 & -1.60 & 3.08 & 14 & 5.79 & -3.39 & 10.94 & 14 & 6.14 & -3.59 & 10.35 & 14 & 5.43 & -2.93 & 7.71 \\
\hline 15 & 5.10 & -3.45 & 8.39 & 16 & 2.76 & -1.55 & 3.38 & 15 & 6.32 & -3.58 & 10.81 & 15 & 6.85 & -3.74 & 11.14 & 15 & 5.91 & -3.08 & 8.27 \\
\hline 16 & 5.58 & -3.80 & 8.40 & 17 & 3.44 & -2.28 & 3.93 & 16 & 6.56 & -3.92 & 10.98 & 16 & 7.37 & -4.45 & 11.39 & 16 & 6.44 & -3.32 & 9.08 \\
\hline 17 & 5.77 & -4.04 & 8.73 & 18 & 3.97 & -2.53 & 4.79 & 17 & 6.99 & -3.87 & 11.41 & 17 & 7.75 & -4.36 & 12.11 & 17 & 6.82 & -3.52 & 9.54 \\
\hline 18 & 6.26 & -4.29 & 9.11 & (S) & (4.38 & $-2.58)$ & $(5.64)$ & 18 & 7.08 & -4.49 & 10.77 & 18 & 8.37 & -4.46 & 12.71 & 18 & 7.25 & -3.95 & 9.91 \\
\hline 19 & 6.50 & -4.44 & 8.75 & 19 & 4.79 & -2.62 & 6.50 & 19 & 7.37 & -4.30 & 11.66 & 19 & 8.65 & -4.84 & 12.57 & 19 & 7.35 & -3.95 & 9.47 \\
\hline 20 & 6.84 & -4.54 & 9.67 & 20 & 5.61 & -3.16 & 7.41 & 20 & 7.66 & -4.35 & 11.96 & 20 & 8.98 & -4.89 & 13.36 & 20 & 7.83 & -4.10 & 9.67 \\
\hline 21 & 7.09 & -4.74 & 9.92 & 21 & 6.68 & -3.36 & 8.69 & 21 & 7.51 & -4.83 & 11.07 & 21 & 9.03 & -5.17 & 13.12 & 21 & 8.02 & -4.25 & 10.41 \\
\hline 22 & 7.38 & -4.98 & 10.04 & 22 & 7.26 & -3.70 & 8.89 & 22 & 7.99 & -4.64 & 11.39 & 22 & 9.17 & -5.41 & 13.11 & 22 & 8.22 & -4.20 & 11.83 \\
\hline 23 & 7.52 & -4.93 & 10.50 & 23 & 7.74 & -3.99 & 9.62 & \multirow{5}{*}{\multicolumn{4}{|c|}{$\left(\begin{array}{lll}\mathrm{CO}-\mathrm{S} & 0.090 & \mathrm{SEC} \\
\mathrm{CO}-22 & 0.252 & \mathrm{SEC}\end{array}\right)$}} & 23 & 9.26 & -5.31 & 13.82 & 23 & 8.21 & -4.44 & 10.42 \\
\hline 24 & 7.72 & -5.03 & 10.24 & 24 & 8.13 & -3.99 & 10.75 & & & & & 24 & 9.41 & -5.22 & 14.42 & 24 & 8.45 & -4.64 & 10.77 \\
\hline 25 & 7.82 & -4.98 & 11.16 & 25 & 8.47 & -3.99 & 10.57 & & & & & 25 & 9.59 & -5.60 & 13.56 & 25 & 8.74 & -4.59 & 11.90 \\
\hline 26 & 8.01 & -5.33 & 10.49 & 26 & 8.57 & -4.14 & 10.15 & & & & & 26 & 9.59 & -5.32 & 14.13 & 26 & 8.69 & -4.97 & 11.20 \\
\hline 27 & 7.86 & -5.18 & 11.12 & 27 & 8.71 & -4.09 & 10.72 & & & & & 27 & 9.31 & -5.22 & 14.09 & 27 & 8.74 & -5.17 & 10.94 \\
\hline 28 & 8.11 & -5.38 & 11.03 & 28 & 8.66 & -4.18 & 11.09 & & & & & \multirow{3}{*}{\multicolumn{4}{|c|}{$\left(\begin{array}{lll}\mathrm{CO}-\mathrm{S} & 0.126 & \mathrm{SEC} \\
\mathrm{CO}-27 & 0.312 & \mathrm{SEC}\end{array}\right)$}} & 28 & 8.84 & -4.98 & 11.59 \\
\hline 29 & 8.30 & -5.18 & 10.94 & 29 & 8.86 & -4.33 & 10.90 & & & & & & & & & 29 & 8.98 & -5.12 & 11.16 \\
\hline & & & & 30 & 8.86 & -4.48 & 10.49 & & & & & & & & & 30 & 8.88 & -5.07 & 11.57 \\
\hline \multirow{3}{*}{\multicolumn{4}{|c|}{$\left(\begin{array}{lll}\mathrm{C} 0-\mathrm{S} & 0.138 & \mathrm{SEC} \\
\mathrm{C} 0-29 & 0.336 & \mathrm{SEC}\end{array}\right)$}} & & & & & & & & & & & & & 31 & 9.08 & -5.12 & 11.77 \\
\hline & & & & & 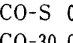 & $.210 \mathrm{~S}$ & & & & & & & & & & 32 & 9.12 & -5.27 & 11.24 \\
\hline & & & & & - & $0.340 \mathrm{SL}$ & & & & & & & & & & 33 & 9.12 & -5.41 & 11.25 \\
\hline & & & & & & & & & & & & & & & & & $0-33$ & 0.007 & \\
\hline
\end{tabular}

なお，すべての移動量計測点は 0.012 秒ごとになって いるので, 総計することにより所要時間も算定できる.

回転量は, C.O. の標識点 TH-MT の角度を $0^{\circ}$ とし, 時計回りの方向を（十）方向として表示し, 単位時間ご との角度として表示した.

\section{3. 計測精度について}

本研究において誤差を生じると考えられるものは， （1）マルチストロボ装置，（2）頭部の動摇，（3）下䫑の側 方偏位，(4) 光学系の収差，（5）ストリーク装置によって フィルムを流す際のフィルムのゆれおよび（6）スポーテ イアスでの座標読み取り時に生じるものが考えられる.

（1）のマルチストロボ装置については，今回使用した 装置は, オイルコンデンサ, SCR によって閃光時間を短
くし，水晶発振によって周波数の精度を向上させたもの であり, 閃光時間は $1.6 \times 10^{-6}$ 秒と非常に短く, 周波数 の精度も $\pm 1 \%$ である。

また発音と同時に発光するスイッチ装置は，マイクロ ホンに音が入ってから発光するまでの時間は $10^{-6}$ 秒の 単位であり，ほとんど無視しても良い，そこで本装置の 使用上での誤差は，声帯からマイクロホンまでの音の伝 わり方に影響されると考えられるので, FH 平面を基準 にした頭部固定装置に, 口唇の前方 $50 \mathrm{~mm}$ にマイクロ ホンが位置するよう固定した.

（2）（5）の頭部の動摇およびフィルムのゆれがあった場 合，撮影したフィルム上に扔いて，フィルムの外縁に対 して，上弓上に固定した標識点 F1，F2，F3，F4 の位直 関係が変化すると考えられる. そこで撮影した後にフィ 
表 6 被験者 6 におおる, 下頡頭の移動, 回転および所要時間 ( $\mathrm{S}$ ：開始位)

\begin{tabular}{|c|c|c|c|c|c|c|c|c|c|c|c|c|c|c|c|c|c|c|c|}
\hline \multicolumn{4}{|c|}{1 回目 } & \multicolumn{4}{|c|}{2 回目 } & \multicolumn{4}{|c|}{3 回目 } & \multicolumn{4}{|c|}{4 回目 } & \multicolumn{4}{|c|}{5 回目 } \\
\hline & 移 & 動 & 回夽 & & 移 & 動 & 回転 & & 移 & 動 & 回転 & & 移 & 動 & 回転 & & 移 & 動 & 回転 \\
\hline & $\mathrm{X}$ & $Y$ & & & $X$ & $Y$ & & & $\mathrm{X}$ & $Y$ & & & $x$ & $Y$ & & & $X$ & $Y$ & \\
\hline 1 & 0.00 & 0.00 & 0.00 & 1 & 0.00 & 0.00 & 0.00 & 1 & 0.00 & 0.00 & 0.00 & 1 & 0.00 & 0.00 & 0.00 & 1 & 0.00 & 0.00 & 0.00 \\
\hline 2 & 0.15 & 0.00 & 0.28 & 2 & 0.10 & -0.35 & 0.38 & 2 & 0.10 & 0.15 & 1.21 & 2 & 0.05 & -0.15 & 0.00 & 2 & 0.40 & -0.01 & 0.11 \\
\hline 3 & 0.40 & -0.25 & 0.03 & 3 & 0.29 & -0.65 & 0.75 & 3 & 0.14 & 0.15 & 1.62 & 3 & 0.40 & -0.65 & 0.13 & 3 & 0.20 & -0.00 & 0.59 \\
\hline 4 & 0.74 & -0.54 & 0.47 & 4 & 0.44 & -1.00 & 0.81 & 4 & 0.10 & 0.10 & 1.73 & 4 & 0.69 & -0.70 & 0.86 & 4 & 0.40 & -0.15 & 0.64 \\
\hline 5 & 1.04 & -0.89 & 1.06 & 5 & 0.84 & -1.44 & 1.12 & 5 & 0.15 & -0.20 & 1.77 & 5 & 1.09 & -0.99 & 2.03 & 5 & 0.59 & -0.25 & 1.02 \\
\hline 6 & 1.48 & -0.89 & 2.79 & 6 & 1.29 & -1.39 & 2.91 & 6 & 0.50 & -0.50 & 1.99 & 6 & 1.28 & -1.39 & 2.20 & 6 & 0.74 & -0.45 & 1.65 \\
\hline 7 & 1.78 & -1.24 & 3.81 & 7 & 1.73 & -1.79 & 3.75 & 7 & 0.74 & -0.79 & 2.48 & 7 & 1.63 & -1.44 & 3.01 & 7 & 1.08 & -0.79 & 2.16 \\
\hline 8 & 2.13 & -1.98 & 3.73 & 8 & 2.38 & -2.39 & 4.02 & 8 & 0.94 & -1.04 & 3.79 & 8 & 1.63 & -1.74 & 3.31 & 8 & 1.33 & -1.28 & 3.35 \\
\hline 9 & 2.82 & -2.62 & 3.86 & 9 & 2.97 & -3.08 & 4.98 & 9 & 1.73 & -1.63 & 4.33 & 9 & 2.07 & -1.98 & 4.62 & 9 & 1.52 & -1.53 & 4.10 \\
\hline 10 & 3.36 & -2.92 & 6.04 & 10 & 3.52 & -3.43 & 6.20 & 10 & 2.27 & -2.03 & 5.16 & 10 & 2.71 & -2.53 & 5.73 & 10 & 2.01 & -1.92 & 4.24 \\
\hline 11 & 4.05 & -3.21 & 7.16 & 11 & 4.41 & -3.68 & 7.12 & 11 & 3.06 & -2.33 & 6.35 & 11 & 3.55 & -3.02 & 6.40 & 11 & 2.26 & -1.97 & 5.52 \\
\hline 12 & 4.84 & -3.51 & 8.23 & (S) & $(4.79$ & $-3.90)$ & $(7.38)$ & 12 & 3.61 & -2.92 & 7.26 & (S) & (3.97 & $-3.32)$ & $(6.56)$ & 12 & 2.60 & -2.47 & 6.14 \\
\hline (S) & $(5.11$ & $-3.66)$ & $(8.67)$ & 12 & 5.16 & -4.12 & 7.64 & (S) & $(4.10$ & $-3.17)$ & $(7.88)$ & 12 & 4.39 & -3.62 & \begin{tabular}{|l|}
6.72 \\
\end{tabular} & 13 & 3.14 & -3.11 & 6.52 \\
\hline 13 & 5.38 & -3.81 & 9.12 & 13 & 5.60 & -4.52 & 8.69 & 13 & 4.59 & -3.41 & 8.51 & 13 & 5.08 & -3.67 & 8.37 & 14 & 3.83 & -3.21 & 7.85 \\
\hline 14 & 5.93 & -4.20 & 9.89 & 14 & 6.30 & -4.87 & 9.28 & 14 & 5.14 & -3.51 & 8.76 & 14 & 5.67 & -4.16 & 8.62 & (S) & 14.25 & $-3.46)$ & $(8.18)$ \\
\hline 15 & 6.67 & -4.25 & 9.83 & 15 & 6.99 & -4.82 & 9.85 & 15 & 5.53 & -3.76 & 10.00 & 15 & 6.41 & -4.46 & 9.50 & 15 & 4.66 & -3.70 & 8.52 \\
\hline 16 & 7.21 & -4.55 & 10.08 & 16 & 7.59 & -5.26 & 10.27 & 16 & 6.12 & -4.16 & 10.33 & 16 & 7.05 & -4.56 & 9.52 & 16 & 5.01 & -3.75 & 9.79 \\
\hline 17 & 7.65 & -4.55 & 10.67 & 17 & 8.23 & -5.36 & 10.16 & 17 & 6.72 & -4.11 & 10.70 & 17 & 7.70 & -4.76 & 10.15 & 17 & 5.99 & -4.05 & 9.90 \\
\hline 18 & 8.25 & -5.04 & 10.54 & 18 & 8.73 & -5.36 & 11.08 & 18 & 7.26 & -4.35 & 10.74 & 18 & 8.24 & -4.56 & 10.95 & 18 & 6.09 & -4.44 & 10.40 \\
\hline 19 & 8.54 & -5.19 & 11.07 & 19 & 9.13 & -5.46 & 11.10 & 19 & 7.60 & -4.50 & 10.11 & 19 & 8.83 & -5.01 & 11.06 & 19 & 6.58 & -4.54 & 10.22 \\
\hline 20 & 9.13 & -5.04 & 11.54 & 20 & 9.52 & -5.71 & 11.19 & 20 & 8.29 & -4.70 & 11.09 & 20 & 9.33 & -5.06 & 10.90 & 20 & 7.22 & -4.54 & 11.08 \\
\hline 21 & 9.58 & -5.24 & 11.64 & 21 & 10.17 & -5.71 & 12.02 & 21 & 8.79 & -4.60 & 11.77 & 21 & 9.87 & -5.21 & 11.40 & 21 & 7.51 & -4.89 & 11.30 \\
\hline 22 & 10.02 & -5.34 & 11.79 & 22 & 10.27 & -5.86 & 11.95 & 22 & 8.94 & -4.75 & 11.54 & 22 & 10.11 & -5.36 & 11.36 & 22 & 7.95 & -4.79 & 12.23 \\
\hline 23 & 10.27 & -5.24 & 11.93 & 23 & 10.96 & -5.66 & 12.78 & 23 & 9.28 & -4.75 & 11.72 & 23 & 10.31 & -5.26 & 11.43 & 23 & 8.10 & -5.08 & 12.15 \\
\hline 24 & 10.71 & -5.24 & 12.55 & 24 & 11.01 & -5.91 & 12.70 & 24 & 9.73 & -5.05 & 11.93 & 24 & 10.86 & -5.16 & 11.34 & 24 & 8.59 & -5.33 & 12.06 \\
\hline \multirow{3}{*}{\multicolumn{4}{|c|}{$\left(\begin{array}{lll}\mathrm{C} 0-\mathrm{S} & 0.138 & \mathrm{SEC} \\
\mathrm{C} 0-24 & 0.276 & \mathrm{SEC}\end{array}\right)$}} & 25 & 11.56 & -5.86 & 13.16 & 25 & 10.17 & -5.00 & 12.06 & & 11.00 & -5.21 & 11.86 & 25 & 8.93 & -5.33 & 11.79 \\
\hline & & & & & & & & 26 & 10.47 & -4.75 & 12.86 & \multirow{3}{*}{$\begin{array}{l}26 \\
27 \\
28 \\
\end{array}$} & 11.15 & -5.26 & 11.59 & \multirow{4}{*}{$\begin{array}{l}26 \\
27 \\
28 \\
29 \\
30\end{array}$} & 9.23 & -5.23 & 12.70 \\
\hline & & & & & $0-5$ & $0.126 \mathrm{~S}$ & & & & & & & 11.45 & -5.12 & 12.87 & & 9.47 & -5.48 & 12.13 \\
\hline & & & & & & 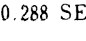 & & & & $138 \mathrm{~S}$ & & & 11.50 & -5.17 & 12.22 & & 9.87 & -5.53 & 12.77 \\
\hline & & & & & & & & & & & & & 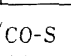 & & & & $\begin{array}{l}10.11 \\
10.41\end{array}$ & $\begin{array}{l}-5.58 \\
-5.58\end{array}$ & $\begin{array}{l}12.37 \\
13.27\end{array}$ \\
\hline
\end{tabular}

ルムの外縁と標識点 F1，F2，F3，F4 の位置関倸に極端 な違いがみられた記録は削除した。

(3) の下顎の側方偏位に対しては，今回の被験者にお いて，下弓上に固定した標識点 TH, MT, M1, M2 の位 置関係に違いがみられなかった.

(4)（6）の光学系の収差およびスポーティアス上の誤差 については，第 1 報 ${ }^{43)}$ に記した測定精度を求めるための 予備垁験に従い, $20.00 \mathrm{~mm}$ 間隔で並べた標識点を本実 験と同様の条件で撮影し，標識点間の距離をスポーティ アス上で計測した. その結果, $20.00 \mathrm{~mm}$ に対して標準 偏差は $\pm 0.05 \mathrm{~mm}$ であったのでこれを本研究における 測定精度とした.

\section{第 3 章 成 樍}

\section{1.下顎頭の移動, 回転および所要時間}

表 1〜 7 は, 被験者 7 名のそれぞれ 5 回のア音発音時 の下顎頭部標識点 TH (以後 TH と略す) の単位時間ご との移動を $\mathrm{x} \cdot \mathrm{y}$ 座標 (表中で移動と表示) で示した. さらに回転については，C.O. の標識点 TH-MT の角度 を $0^{\circ}$ とした時の単位時間ごとの角度（表中で回転と表 示）で示した. また，C.O. からア音開始位までの所要時 間（表中で CO-S と表示）と，下顎頭の停止位までの所 要時間（表中で CO-停止した番号で表示）を示した.

番号 1 が出発点の C.O、で, $2,3, \cdots \cdots$ と変化し, 各番 号間は 0.012 秒の間隔である. S はア音開始位であり, 被験者 1 の 1 回目のア音開始位は 0.162 秒後で, 0.240 
表 7 被験者 7 における, 下瀕頭の移動，回転および所要時間（S：開始位）

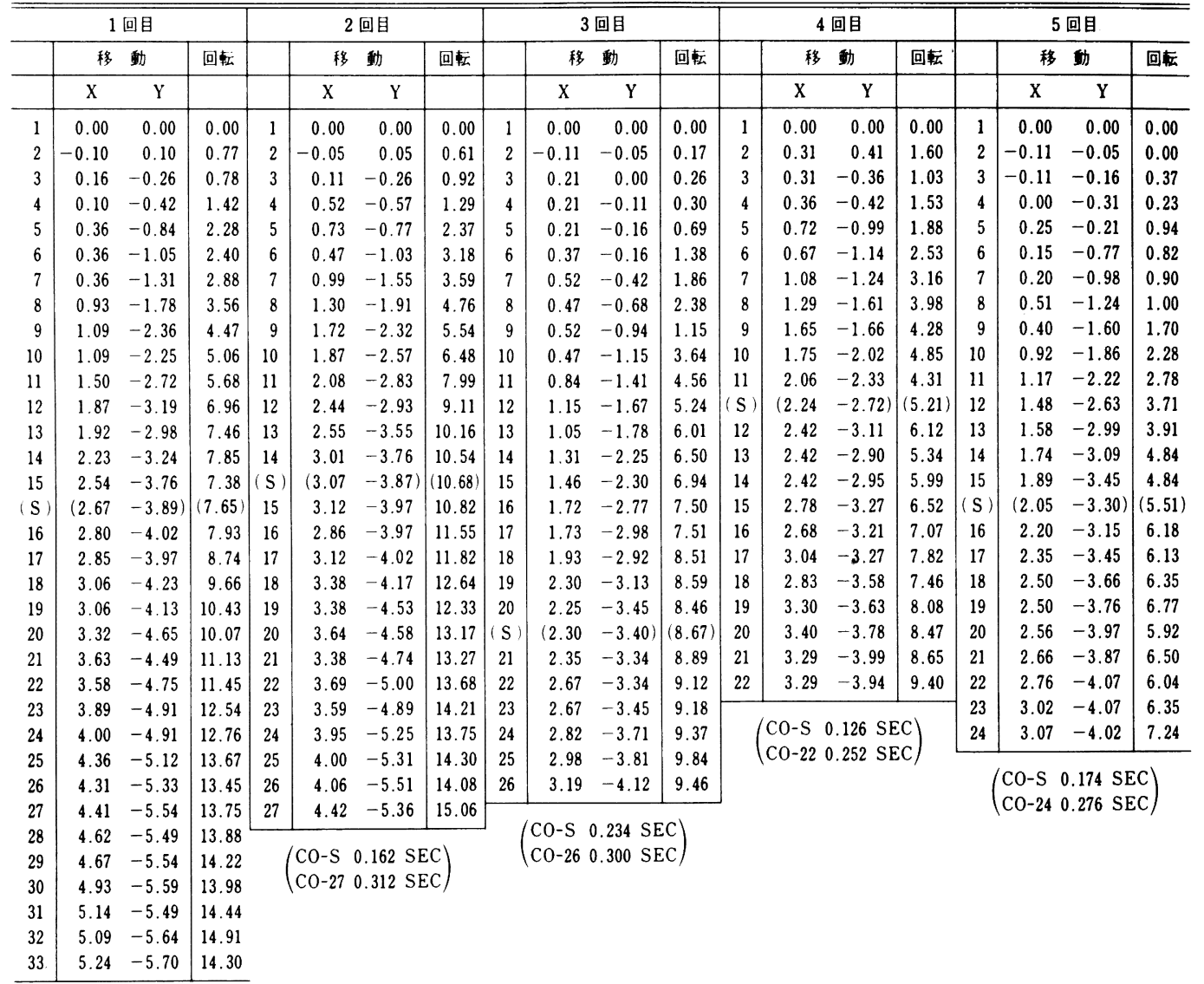

$\left(\begin{array}{lll}\mathrm{CO}-\mathrm{S} & 0.174 & \mathrm{SEC}\end{array}\right)$

$\left(\begin{array}{lll}\mathrm{CO}-33 & 0.384 & \mathrm{SEC}\end{array}\right)$

秒後の 21 で停止している. この停止位は引き続きア音 を発音している位置である.

図2〜8は，それぞれの被験者の 5 回のア音発音時の 出発点 (C.O.) から停止位までの TH の移動状態をグラ フに示したものである.

表 8-a, b , c と図 9-a, b, c に, 各被験者の C.O. から 開始位および C.O. から停止位までの下顎頭の移動量と, 回転量および所要時間のそれぞれ 5 回の平均值と $95 \%$ 信頼区間を，表 9〜12 に統計学的に有意差を検討した結 果を示す。

\section{第 4 章＼cjkstart総括および検討}

\section{1. 実験方法について}

下顡運動の様相を知るために従来から, 描 記 法 $2 \sim 4,16$, 20)，写真撮影法1,5,9 13, 19, 28)，X線撮影法 6 8, 18,23,35,36) お よび電気的測定法 $14,15,17,21,22,24 ~ 27,29)$ 等が応用されてい る. いずれも切歯点の運動様相を測定し，その後計算に より下買頭付近の運動パターンを求めているものが多 い. 一般に発音時の下額頭の運動は, 移動量が小さくか つ高速であるので，解析が困難であり詳細に解明されて いない，この運動を解析するためには，測定部を下頡頭 部に設定し, 非接触的に運動を測定記録できるものが要 求され，写真撮影法の応用が考えられる. この写真撮影 


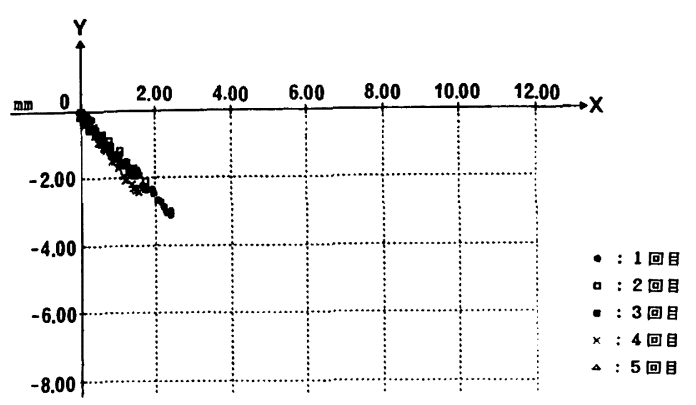

図 2 被験者 1 における, 下䫑頭の移動

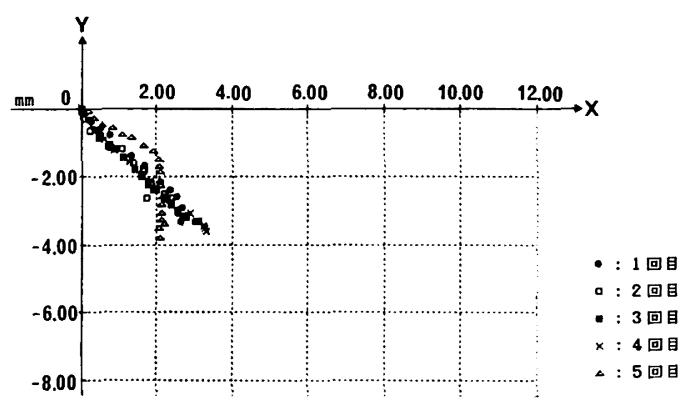

図 3 被検者 2 における,下顎頭の移動

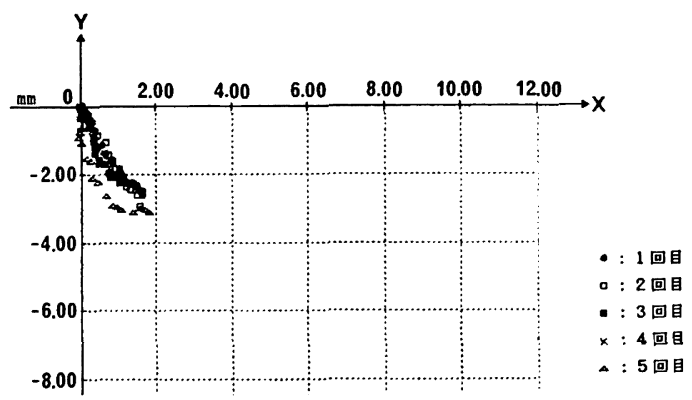

図 4 被験者 3 における，下頡頭の移動

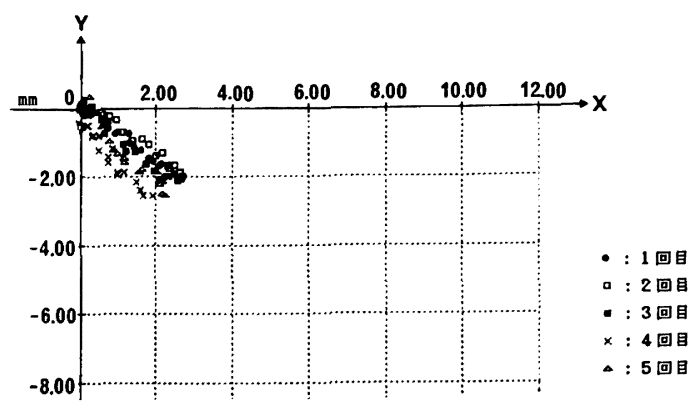

図 5 被験者 4 における, 下顎頭の移動

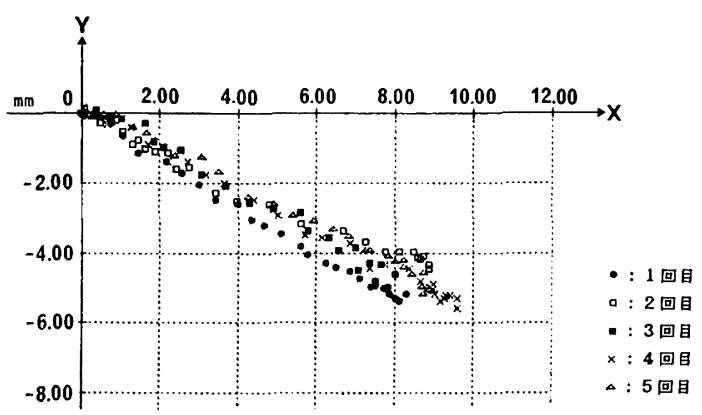

図 6 被験者 5 における、下䫟頭の移動

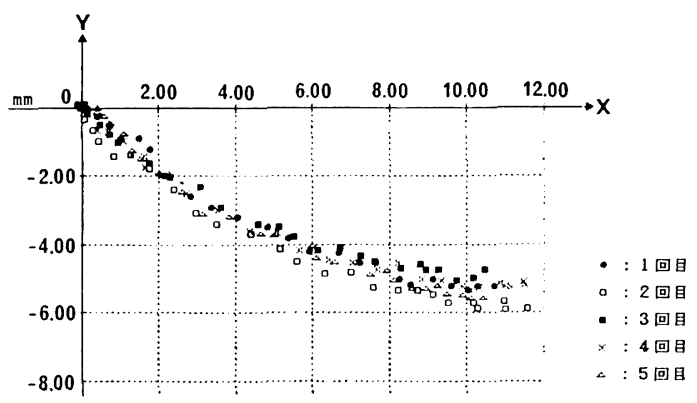

図 7 被験者 6 にお拈る, 下影頭の移動

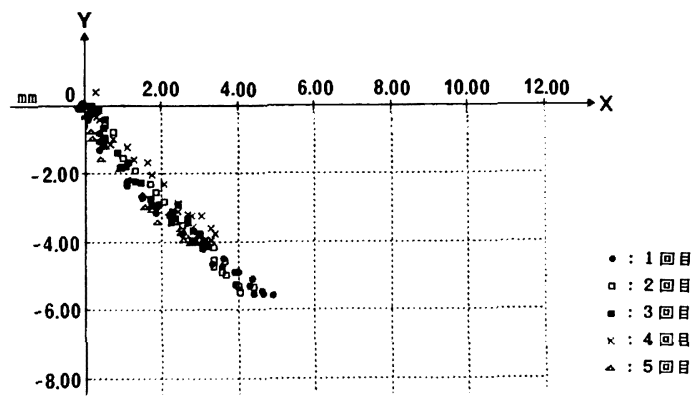

図 8 被験者 7 におうる, 下影頭の移動

法の光源として, 著者は閃光時 閒 が $1.6 \times 10^{-6}$ 秒 と 短 い, マルチストロボ装置を応用し，0.012 秒間隔で繰 返 し発光し, 連続写真を撮影する装置を開発した. これを 用い, C.O. を出発点としア音発音時の下顎頭運動様相を 記録できるものとした. さらに発音侍の下䫑頭の移動, 回転および所要時間を知るために，マイクにより集音す ると同時にストロボ装置を自動発光させるスイッチ装置 を開発した．以上により，ア音発音時の下頡頭の移動， 回転, そしてその所要時間の全体像を明らかにすること ができ，十分なる精度をもって，機能運動の様相を解析 可能とした. 
表 8-a 各被験者における，C.O. から開始位， 停止位までの移動量

\begin{tabular}{l|c|rr}
\hline & CO-開始位 & \multicolumn{2}{|c}{ CO-停止位 } \\
\hline Sub. 1 & $2.31(1.49 \sim 3.13)$ & 3.02 & $(2.12 \sim 3.92)$ \\
Sub. 2 & $2.89(2.65 \sim 3.13)$ & 4.69 & $(4.26 \sim 5.12)$ \\
Sub. 3 & $2.44(1.72 \sim 3.15)$ & 3.31 & $(2.45 \sim 4.17)$ \\
Sub. 4 & $2.85(1.99 \sim 3.72)$ & 4.90 & $(4.31 \sim 5.48)$ \\
Sub. 5 & $5.29(3.97 \sim 6.60)$ & $11.68(10.59 \sim 12.77)$ \\
Sub. 6 & $6.15(5.57 \sim 6.71)$ & $13.37(12.68 \sim 14.06)$ \\
Sub. 7 & $5.23(4.71 \sim 5.75)$ & 8.07 & $(6.29 \sim 9.85)$ \\
\hline
\end{tabular}

5 回の平均, ( ): $95 \%$ 信頼区間

単位：mm

表 8-b 各被験者における，C.O. 加ら開始位， 停止位までの回転量

\begin{tabular}{c|c|rr}
\hline & \multicolumn{2}{|c|}{ CO-開始位 } & \multicolumn{2}{|c}{ CO-停止位 } \\
\hline Sub. 1 & $5.19(4.67 \sim 5.71)$ & 6.66 & $(5.87 \sim 7.44)$ \\
Sub. 2 & $5.22(3.96 \sim 6.47)$ & 6.42 & $(4.26 \sim 8.57)$ \\
Sub. 3 & $6.85(4.36 \sim 9.34)$ & 7.60 & $(4.97 \sim 10.22)$ \\
Sub. 4 & $5.03(3.20 \sim 6.86)$ & 7.36 & $(6.25 \sim 8.48)$ \\
Sub. 5 & $6.51(5.28 \sim 7.74)$ & 11.63 & $(9.87 \sim 13.39)$ \\
Sub. 6 & $7.73(6.73 \sim 8.74)$ & 12.81 & $(12.27 \sim 13.34)$ \\
Sub. 7 & $7.54(4.72 \sim 10.37)$ & 11.09 & $(6.86 \sim 15.32)$ \\
\hline
\end{tabular}

5 回の平均, ( ): $95 \%$ 信頼区間

単位：度

表 8-c 各被験者における，C.O. から開始位， 停止位までの所要時間

\begin{tabular}{|c|c|c|}
\hline & $\mathrm{CO}$-開始位 & $\mathrm{CO}-$ 停止位 \\
\hline Sub. 1 & $0.131(0.087 \sim 0.175)$ & $0.197(0.153 \sim 0.241)$ \\
\hline Sub. 2 & $0.115(0.092 \sim 0.138)$ & $0.194(0.156 \sim 0.233)$ \\
\hline Sub. 3 & $0.150(0.138 \sim 0.162)$ & $0.211(0.194 \sim 0.228)$ \\
\hline Sub. 4 & $0.138(0.116 \sim 0.160)$ & $0.238(0.209 \sim 0.266)$ \\
\hline Sub. 5 & $0.140(0.086 \sim 0.195)$ & $0.326(0.265 \sim 0.387)$ \\
\hline Sub. 6 & $0.140(0.124 \sim 0.157)$ & $0.310(0.271 \sim 0.348)$ \\
\hline Sub. 7 & $0.174(0.126-0.222)$ & $0.305(0.243 \sim 0.367)$ \\
\hline
\end{tabular}

表 9 各被駼者に㧍ける，C.O. 加ら開始位までの变位 星・所要時間と, 停止位までの変位量・所要時間と の間の有意差の検定

\begin{tabular}{|c|c|c|c|c|c|c|c|}
\hline Sub. & 1 & 2 & 3 & 4 & 5 & 6 & 7 \\
\hline 移動 量 & & ** & & ** & ** & $*$ & ** \\
\hline 回 転 量 & $* *$ & & & * & $* *$ & $* *$ & \\
\hline 所要時間 & • & ** & ** & ** & $*$ & $* *$ & $* *$ \\
\hline
\end{tabular}

注 : : 危険率 $5 \%$ で有意

**:危険率 $1 \%$ で有意

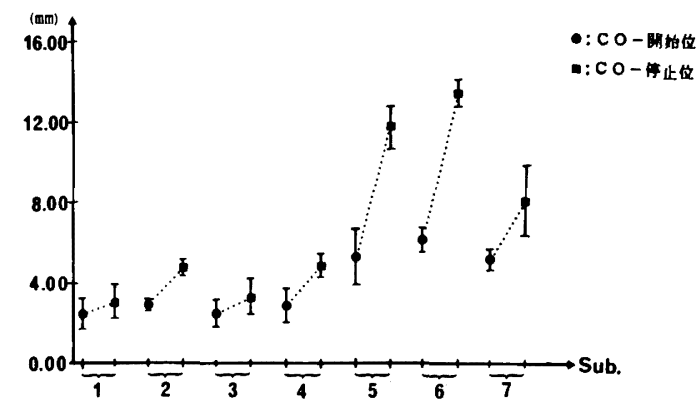

図 9-a 各被験者における，C.O. 加ら開始位， 停止位までの移動量

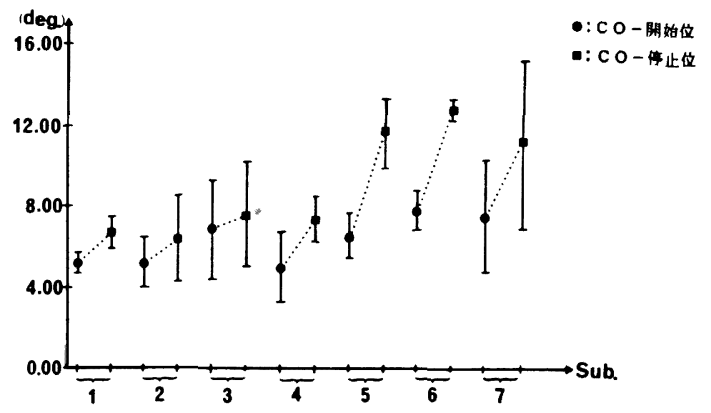

图 9-b 各被験者における，C.O. 加ら開始位， 停止位までの回転量

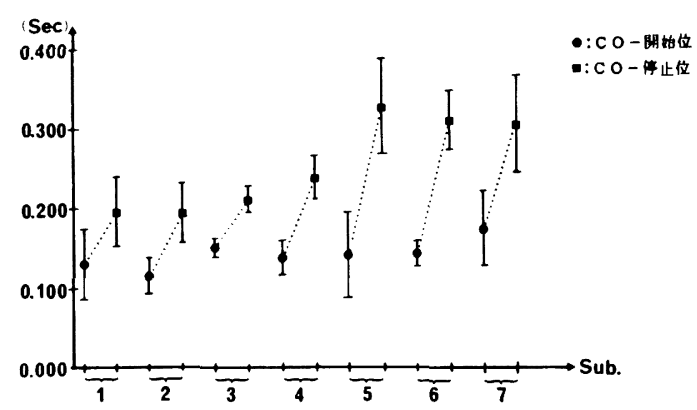

図 9-c 各被験者における, C.O. 加ら開始位, 停止位までの所要時間

このことは，今までの諸研究を発展させた新しい下䪽 運動のアプローチであろうと推察する.

\section{2. 計測結果について}

1) 移動量, 回転量および所要時間について

下顎運動の研究の中で, 機能時, 特に発音時の下顎運 動については，義歯作製時の咬合高径の設定や前歯部の 排列位置, 被蓋関係の決定を目的として，その多くが前 歯部の運動について研究解明されている ${ }^{12,22,23,35 ~ 42)}$. 特 
表 10 移動量における，被験者間の有意差の検定

CO-開始位

\begin{tabular}{c|c|c|c|c|c|c}
\hline \hline 2 & 3 & 4 & 5 & 6 & 7 & Sub. \\
\hline & & & $* *$ & $* *$ & $* *$ & 1 \\
& & & $* *$ & $* *$ & $* *$ & 2 \\
& & $* *$ & $* *$ & $* *$ & 3 \\
& & $* *$ & $* *$ & $* *$ & 4 \\
& & & & 5 \\
\end{tabular}

CO-停止位

\begin{tabular}{c|c|c|c|c|c|c}
\hline \hline 2 & 3 & 4 & 5 & 6 & 7 & Sub. \\
\hline$* *$ & & $* *$ & $* *$ & $* *$ & $* *$ & 1 \\
& $* *$ & & $* *$ & $* *$ & $* *$ & 2 \\
& $* *$ & $* *$ & $* *$ & $* *$ & 3 \\
& & $* *$ & $* *$ & $* *$ & 4 \\
& & & $* *$ & $* *$ & 5 \\
\end{tabular}

注：表 9 の注を参照

表 11 回転量における，被験者間の有意差の検定

\section{CO-開始位}

\begin{tabular}{c|c|c|c|c|c|c}
\hline \hline 2 & 3 & 4 & 5 & 6 & 7 & Sub. \\
\hline & & & $*$ & $* *$ & & 1 \\
& & & & $* *$ & & 2 \\
& & & & & & 3 \\
& & & $* *$ & & 4 \\
& & & & & \\
\end{tabular}

CO-停止位

\begin{tabular}{c|c|c|c|c|c|c}
\hline \hline 2 & 3 & 4 & 5 & 6 & 7 & Sub. \\
\hline & & & $* *$ & $* *$ & $*$ & 1 \\
& & & $* *$ & $* *$ & $*$ & 2 \\
& & & $* *$ & $* *$ & & 3 \\
& & $* *$ & $* *$ & & 4 \\
& & & & & 5 \\
\hline
\end{tabular}

注：表 9 の注を参照

表 12 所要時間における, 被験者間の有意差の検定

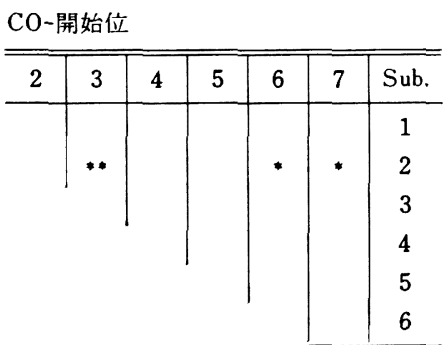

に子音については S 音で多くの研究がみられ, $\mathrm{S}$ 発音位 は全発音位中最も下顎の位置安定性が高く22,23,38,41)，乙 かも上下顎前歯が最も接近し $12,23,38,40,41)$, 前歯部被蓋度 と関係 $23,37,38,40)$ も梁いことが知られている. また， $\mathrm{S}$ 発 音時に下顎は移動しており, その移動量は後続母音の影 響をうけていると報告されている23,42). さらに実験的に 前歯部被蓋度や咬合高径を変化させると, S 発音に歪み が生じる23,37,41)などと報告されている，また，母音につ いては, 切歯点の調音運動は上下運動が前後運動よりは るかに優勢で明瞭であり ${ }^{39)}$ ，ア音は顎間距離が $5 \mathrm{~mm}$ 以 下になると， 口腔容積の減少のために音色が変化する ${ }^{37)}$

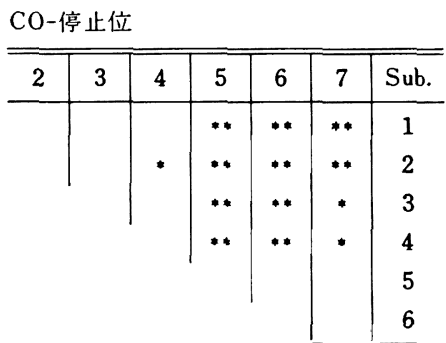

注 : 表 9 の注を参照

などと報告されている.

一方下頡運動の中で, 下顎頭部の移動と回転という運 動についてみると，限界運動や習慣的開閉運動における 研究9,19,30,32) がみられ，下顎頭部の運動路は測定点のわ ずかな位直の違いにより大きく変化することが知られて いる ${ }^{9,19)}$. また前方滑走運動では下顎頭部はほとんど回 転せず ${ }^{19)}$, 習慣的な開口運動時の下顎頭は，移動と回転 との割合がともに一様に変化した ${ }^{32)}$ と報告されている. しかし，生理的機能運動時，特に発音時の下䫟頭部の移 動と, 回転という運動に関する研究はみられない.

そこで今回著者は，生理的な下顥頭部の運動を解明す 
る第 1 段階として，前歯部の被蓋や咬合高径の影響を受 けにくく，その運動様相を把握しやすいア音をとりあ げ，マルチストロボ装置を応用した写真撮影法により， ア音発音時の下䫅頭部の移動量，回転量および所要時間 について計測し，さらに移動と回転という要素の関係を 時間的な対応をもたせて検討を行った.

ア音発音時の C.O. からア音開始位までと, C.O. から 停止位までとの間の下顎頭部の移動量の有意差を検定し たところ, Sub. 1 と 3 を除き他の 5 例で有意差を認めた (表 9).これによりア音発音時の両者の位置における，下 䫟頭部の移動量に差があることが判明した．被験者間の 有意差検定の結果（表 10）では， C.O. からア音開始位ま では, Sub. 1〜4 と Sub. 5〜7 との移動量の異なる 2 グ ループに分れる傾向が認められた. また C.O. から停止 位までは, Sub. 1 と 3， 2 と 4 の間を除き他の被験者間 の移動量に有意差が認められた.

ア音発音時の C.O. からア音開始位までと, C.O. から 停止位までとの間の下颚頭部の回転量の有意差を検定し たところ, Sub. 2，3，7 を除き他の 4 例で有意差を認め た (表 9 ).これによりア音発音時の両者の位置におけ る，下頡頭部の回転量に差があることが判明した．被験 者間の有意差検定の結果 (表 11) では, C.O. からア音開 始位までは一定の傾向はみられなかったが，C.O.から停 止位までは, Sub. 1〜4 と Sub. 5〜7 との回転量の異な る 2 グループに分れる傾向が認められ.

ア音発音時の C.O. からア音開始位までと，C.O. から 停止位までとの間の所要時間の有意差を検定したとこ ろ、すべての被験者で有意差を認めた（表 9)。これによ り，ア音発音時の両者の位置における下䪽頭変位の所要 時間には，時間的に差があることが判明した．被験者間 の有意差検定の結果（表 12）では，C.O. からア音開始位 までは, Sub. 2 と 3, 6, 7 との間を除いて有意差を認め ず, C.O. から停止位までは, Sub. 1〜4 と Sub. 5〜7 と の所要時間の異なる 2 グループに分れる傾向が認められ た.

ア音発音時の下頡運動に関する過去の研究をみると, 三谷 ${ }^{39}$ は 5 名の被験者の切歯点での発音時の下䫟運動に 関する研究において, ア音発音時の開口量は, 発音開始 位が最小であった被験者では $16.0 \mathrm{~mm}$ でその時の最大 開口量は $17.0 \mathrm{~mm}$ であり，発音開始位が最大であった 被験者では $30.9 \mathrm{~mm}$ で, その時の最大開口量は 32.9 $\mathrm{mm}$ であったと報告している. 著者の研究では，切歯点 部の開口量を計測していないため, 直接開口量として比 較できないが, 矢状面での下䫑頭と切歯点との距離を
$90 \mathrm{~mm}$ と仮定し, 本研究の下䫟頭部の回転量 と, 前下 方への移動量のうちの下方, すなわち $\mathrm{y}$ 成分の変位量の 平均値により, 切歯点部の開口量を計算して求めると, 最小はSub. 4 で, C.O. からア音開始位までが $8.9 \mathrm{~mm}$, 停止位までが $13.7 \mathrm{~mm}$ であり, 最大は Sub. 6 で C.O. からア音開始位までが $15.6 \mathrm{~mm}$, 停止位までが $25.5 \mathrm{~mm}$ であった.この値と先の三谷 ${ }^{399}$ の結果を比較すると, 著 者の值は, 開口量がやや小さい傾向であった.

またア音開始位と停止位という位置について考察して みると，音声が始まる位置をア音開始位とし，ア音を継 続して発音できる位置を停止位と設定したので, 両位置 はともにア音を発音できる. 三谷 ${ }^{39}$ の研究においても, ア音発音時下顎切歯点の位置が上下的に変化したとして おり, 古屋 ${ }^{23)}$ は子音に続く後続母音においては同じ母音 でも下顎位の範囲は大きく変化し，その先行子音によっ ても位置が大きく変化したと報告している．本研究にお いても切歯点の運動量に大きく影響する回転量は, 被験 者ごとにばらつきが大きく，一定の傾向も明瞭ではな く，ア音発音時の下顎位が特に上下方向で広い範囲に存 在していることを示している.

また下頷頭の移動量，回転量および所要時間について みると，各被験者ごとにそれぞればらつきはみられるも のの, C.O. から停止位までの変位に比べ C.O. からア音 開始位までの変位量のばらつきは小さく，特にア音発音 時の所要時間では被験者 7 名をとおして一定の值となる 傾向を示した（図 9-c).

このことより，発音時にほぼ同距離の開口移動をもっ て発音するというパターンが存在することが明らかとな った.

2） C.O. から停止位までの変位量に対する，ア音開始 位までの変位量の比率について

C.O. から停止位までの下顎頭の移動量，回転量およ び所要時間に対する, ア音開始位までの移動量, 回転量 および所要時間の比率の 5 回平均值, $95 \%$ 信頼区間およ び統計学的検討結果を表 13〜15 に示した. この表をグ ラフに示したのが図10である.

ここでは，ア音開始位が下䅡頭部の全体の変位量のど の位置に存在するか，ア音開始位の前後で移動と回転が どのように関連しているかを検討するため, それぞれ比 率を求めた。

各被験者の平均についてみると（表 13），移動では最 小 0.45 から最大 0.76 , 回転では 0.56 から 0.90 , 所要時 間では 0.427 から 0.711 であった.このことから， ア 音開始位といら位置は全体の下罰頭の運動中の後半に位 
表 13 各被験者における，C.O. から停止位までの変位量に対する 開始位までの変位量の比率

\begin{tabular}{|c|c|c|c|}
\hline & 移 & 転 & 所 要 時 間 \\
\hline Sub. 1 & $0.76(0.70 \sim 0.82)$ & $0.78(0.74 \sim 0.82)$ & $0.656(0.580 \sim 0.732)$ \\
\hline Sub. 2 & $0.62(0.54 \sim 0.69)$ & $0.83(0.70 \sim 0.96)$ & $0.594(0.544 \sim 0.644)$ \\
\hline Sub. 3 & $0.71(0.62 \sim 0.80)$ & $0.90(0.86 \sim 0.94)$ & $0.711(0.647 \sim 0.775)$ \\
\hline Sub. 4 & $0.58(0.47 \sim 0.69)$ & $0.68(0.48 \sim 0.88)$ & $0.583(0.496 \sim 0.670)$ \\
\hline Sub. 5 & $0.45(0.35 \sim 0.55)$ & $0.56(0.53 \sim 0.59)$ & $0.427(0.301 \sim 0.553)$ \\
\hline Sub. 6 & $0.46(0.41 \sim 0.51)$ & $0.60(0.53 \sim 0.68)$ & $0.455(0.413 \sim 0.496)$ \\
\hline Sub. 7 & $0.66(0.54 \sim 0.77)$ & $0.69(0.49 \sim 0.89)$ & $0.576(0.414 \sim 0.739)$ \\
\hline
\end{tabular}

5 回の平均, （ ）: 95\%信頼区間

表 14 各被験者における，C.O. から停止位までの変位量 に対する開始位までの変位量の比率における，移動 と回転との間の分散比の検定

\begin{tabular}{r|l|l|l|l|l|l|l}
\hline Sub. & 1 & 2 & 3 & 4 & 5 & 6 & 7 \\
\hline & & &
\end{tabular}

表 15 各被験者における，C.O. から停止位までの变位量 に対する開始位までの変位量の比率における, 移動 と回転との間の有意差の検定

\begin{tabular}{|c|c|c|c|c|c|c|c|}
\hline Sub & 1 & 2 & 3 & 4 & 5 & 6 & 7 \\
\hline 移動一回転 & & $*$ & $*$ & & * & $* *$ & \\
\hline
\end{tabular}

注：表 9 の注を参照

㯰していることが明らかとなった．

比率によって無単位化した移動と回転との間の分散比 を検定した結果（表 14）では, Sub. 5 以外のすべての被 験者において差を認めなかった. このことから移動と回 転との間で有意差検定して良いと考えられる，移動と回 転との間の有意差検定結果（表 15）では, Sub. 1，4，7 で差が認められなかったが，平均值（表 13）で比較する と，すべての被験者において回転が大である傾向であっ た.この結果よりア音開始位まででは，下䫟頭部の回転 の要素が移動に先行しているものと推察される. しかし 福島 ${ }^{32)}$ は, 習慣的開閉運動の研究において，開口運動時 の移動と，回転の割合がともに一様に変化したと報告し ている.このことは，本研究とは測定点が異なるため直 接比較できないが，習慣的開口運動と発音時の開口運動 とは，その様相が異なることを示しており，両者の間に は生理学的な反射機構に違いが存在するのではないかと 考えられる.

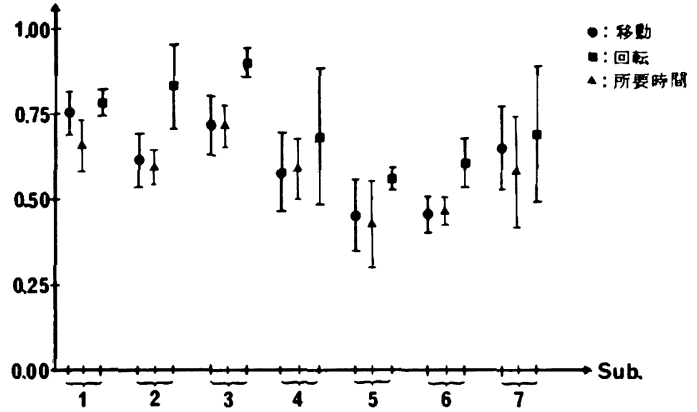

図 10 各被験者におうる，C.O. から停止位までの変位量 に対する，開始位までの変位量の比率

3）停止位までの所要時間に対応する変位量の比率 発音時の下顎頭の停止位までの総所要時間を前期・中 期・後期とに 3 等分し，全体の総変位量に対するこれら の各期における変位量の比率について，5回の平均值お よび 95\% 信頼区間を表 16-a，b に示した.この表をグ ラフに示したのが図11-a, b である.

前期 · 中期 ·後期を平均值で比較すると, 移動 ·回転 ともに前期・後期に比べ中期で大きな值を示した. すな わち, 運動の速度はその運動の中期が最も速いことを示 している. この傾向は, 三谷 ${ }^{39)}$ の研究でも同様なことを 報告しており，また習慣的開閉運動に関する報告1,30 32) とも一致している．移動では中期の移動量が大きいこと は共通に認められるが，後期が小さい傾向は認められな い.しかし回転においてはすべて中期の回転量の比率が 大きく，常に前期に比べ後期が小さな傾向を示した. こ のことは, 回転はその多くはア音発音時の前期・中期に 起こっていることになり，その速度変化は動きはじめて 比較的早期に最高速度になり, 所要時間の中間点でほぼ 停止位に近うき，比較的低速度で徐々に速度を减じなが ら停止位に向かうという傾向であると推察される. 
表 16-a 各被験者における，C.O.から停止位までの移動量に対する 前期・中期・後期の移動量の比率

\begin{tabular}{l|c|c|c}
\hline \hline & 前期/CO-停止位 & 中期/CO-停止位 & 後期/CO-停止位 \\
\hline Sub. 1 & $0.37(0.28 \sim 0.46)$ & $0.40(0.35 \sim 0.45)$ & $0.23(0.14 \sim 0.32)$ \\
Sub. 2 & $0.28(0.19 \sim 0.36)$ & $0.41(0.38 \sim 0.44)$ & $0.32(0.25 \sim 0.38)$ \\
Sub. 3 & $0.19(0.10 \sim 0.28)$ & $0.46(0.38 \sim 0.55)$ & $0.34(0.29 \sim 0.40)$ \\
Sub. 4 & $0.28(0.20 \sim 0.36)$ & $0.36(0.28 \sim 0.43)$ & $0.36(0.32 \sim 0.40)$ \\
Sub. 5 & $0.30(0.21 \sim 0.38)$ & $0.45(0.41 \sim 0.48)$ & $0.26(0.19 \sim 0.33)$ \\
Sub. 6 & $0.27(0.23 \sim 0.31)$ & $0.46(0.42 \sim 0.50)$ & $0.27(0.22 \sim 0.33)$ \\
Sub. 7 & $0.33(0.24 \sim 0.41)$ & $0.39(0.33 \sim 0.46)$ & $0.28(0.22 \sim 0.34)$ \\
\hline
\end{tabular}

5 回の平均, ( ):95\% 信頼区間

表 16-b 各被験者におうる，C.O. から停止位までの回転量に対する 前期・中期・後期の回転量の比率

\begin{tabular}{c|c|c|c|c}
\hline \hline & 前期/C O - 停止位 & 中期/C O - 停止位 & \multicolumn{1}{|c}{ 後期/C 0 - 停止位 } \\
\hline Sub. 1 & $0.31(0.18 \sim 0.44)$ & $0.46(0.37 \sim 0.54)$ & $0.23(0.10 \sim 0.35)$ \\
Sub. 2 & $0.25(0.08 \sim 0.41)$ & $0.62(0.44 \sim 0.81)$ & $0.13(-0.01 \sim 0.27)$ \\
Sub. 3 & $0.27(0.12 \sim 0.43)$ & $0.57(0.45 \sim 0.69)$ & $0.16(0.08 \sim 0.24)$ \\
Sub. 4 & $0.36(0.27 \sim 0.45)$ & $0.42(0.23 \sim 0.61)$ & $0.22(0.02 \sim 0.41)$ \\
Sub. 5 & $0.40(0.23 \sim 0.57)$ & $0.48(0.39 \sim 0.57)$ & $0.12(-0.05 \sim 0.28)$ \\
Sub.6 & $0.36(0.28 \sim 0.45)$ & $0.47(0.39 \sim 0.54)$ & $0.18(0.12 \sim 0.23)$ \\
Sub. 7 & $0.29(0.11 \sim 0.47)$ & $0.51(0.27 \sim 0.74)$ & $0.21(0.13 \sim 0.28)$ \\
\hline
\end{tabular}

5 回の平圴], ( ) : 95\%信頼区間

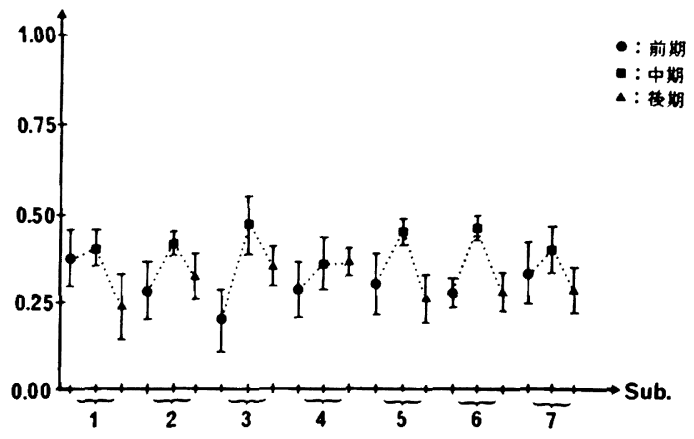

図 11-a 各被験者における，C.O．から停止位までの移動 量に対寸る，前期・中期・後期の移動量の比率

移動と回転を比較すると，前期では一定の傾向はみら れないが，中期では回転が大きく，後期では移動が大き い傾向であった．以上により回転の要素は常に移動に先 行して起こると考えられる.

以上を総括すると，一般に発音時の下顎運動は反射的 な運動と考えられており，その機構は複雑で知覚系と運 動系との間の相互作用により，自分の表現したい言葉を 合成し，発音し，しかもその音を聞きながら，開口量を 調節するような複雑な矨運動が生じる ${ }^{45)}$ といわれてい

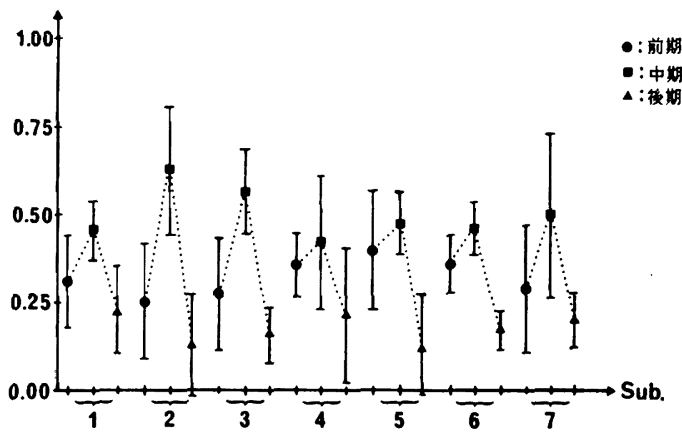

図 11-b 各被験者におうる，C.O.から停止位までの回転 量に対する，前期・中期・後期の回転量の比率

る.このことは, 本研究において被験者内および被験者 間のばらつきが大きく表れていることによってむ明らか である.しかし，ア音発音時の下頸運動は，習慣的開口 運動と異なり，まず回転を主体に比較的一定なア音開始 位へと運動し, その後ア音発音位へと移動を主体として 運動していると考えられる.

さらに, 本研究に扔ける被験者は顎口腔系に機能異常 特に発音, 談話に異常のみられない者のみを対象として いるが，顎関節症患者のような顎口腔系に機能異常を有 
する者に対して同様に測定し，移動と回転の関連につい て検討すれば診断の一助ともなり得ると考えられる.

\section{第 5 章 結 論}

今回著者は，頻口腔系に異常が認められず，日常談話 に異常のみられない 7 名の被験者に対して，2組のマル チストロボ装置を応用し，一方を 0.012 秒間隔の繰返し 閃光させ，他方を発音と同時に発光させ，それぞれの閃 光を光ファイバーにて 8 つ標識点とした. 写真撮影法 により最大咬頭嵌合位を出発点として，歯および咬合関 係の影響を受けにくいア音発音時の下顎頭運動を撮影記 録し，解析した結果，以下の結論を得た.

1） ア音発音開始位までの下頡頭の移動量，回転量お よび所要時間は，7名の被験者においてほぼ一定の值を 示す傾向であった。

2）最大咬頭嵌合位からア音発音開始位までの下顎頭 の移動量は, $2.31 \mathrm{~mm}$ から $6.15 \mathrm{~mm}$, 回転量は 5.03 度 から 7.73 度および所要時間は 0.115 秒から 0.174 秒で あった。

3）最大咬頭峳合位からア音発音時に下䫑運動を停止 する位置までの移動量は $3.02 \mathrm{~mm}$ から $13.37 \mathrm{~mm}$, 回転 量は 6.42 度から 12.81 度および所要時間は 0.194 秒か ら0.326 秒であった.

4）了音発音開始位の前・後で比較すると，下頡頭の 回転は移動に比べ, 早期に起こる傾向であった.

5）ア音発音時の下顎頭運動全体を 3 期に分けて比較 すると, 移動・回転ともにその変化する速度は中期が速 い傾向であった．また回転においては前期に比べ後期の 回転量が小さい傾向であった.

6）本研究の結果からすると，ア音発音時の下䫑頭の 運動は，まず回転を主体に，比較的一定な位置へと運動 し，その後，ア音発音に最適な位置へと移動を主体とし て，運動していると考えられる.

稿を終わるにあたり，本研究に際しご校閲を賜りました日本 大学五十嵐孝義教授ならびに本研究に淔接ご指導賜った日本大 学中澤 靖教授と実験に直接ご指導いただいた日本大学工藤忠 男講師に深甚なる感謝の意を表します. またご専攻の立場から ご指導を賜りました日本大学大木一三教授, 戸田善久教授, 森 谷良彦教授に深く感謝の意を表します.

あわせて, 日頃ご助言ご鞭撻を頂きました歯科補緅学第 3 講 座医局員各位，大学院生各位ならびに本研究にご協力を頂きま した被験者各位に対し感謝の意を表します。

\section{Summary}

Many reports have been made by researchers in the past on the study of the mandibular movement, which is a matter of primary concern in prosthodontics. It has been made clear by these reports that the movements of mandibular condyle can be divided into two kinetic elements of translation and rotation. However, almost no report has been made so far concerning in what temporal process these two elements occur at the time of physiologic condyle movement, especially when phonation is made.

Therefore, the author particulary took up the phonation of the [a:] sound, which is least influenced by occlusion and the vertical and horizontal overlap of the anterior. The author then paid attention to the movement of mandibular condyle when the [a:] sound was pronounced. And in order to serve for the diagnosis of dysfunction of the stomatognathic system, the subjects used for the present experiment were limited to those who had no abnormality in their stomatognathic system. By photographic analysis using a multiple stroboscope apparatus, and considering the time element, the author recorded and analyzed the translation and rotation of mandibular condyle, and reached the following conclusion.

1) All the seven subjects tended to show very little difference in the amount of translation and the degree of rotation of their mandibular condyle, as well as in the time required until it came to the position ready to pronounce the $[\mathrm{a}:]$ sound.

2) The amount of translation of mandibular condyle from the position of maximal intercuspal occlusion to that when the $[\mathrm{a}:]$ sound was ready to be pronounced was between $2.31 \mathrm{~mm}$ and $6.15 \mathrm{~mm}$; the degree of rotation was between $5.03^{\circ}$ and $7.73^{\circ}$; and the time required was between 0.115 and 0.174 seconds.

3) The amount of translation from the position of the maximal intercuspal occlusion to that when the mandibular movement stopped with the pronunciation of the [a:] sound was between $3.02 \mathrm{~mm}$ and $13.37 \mathrm{~mm}$; the degree of rotation was between $6.42^{\circ}$ and $12.81^{\circ}$; and the time required was between 0.194 and 0.326 seconds.

4) When compared before and after the [a:] sound was pronounced, the rotation of mandibular condyle tended to occur earlier than translation.

5) When comparison was made by dividing the entire movement of mandibular condyle into three periods, the 
speed of change, both in translation and rotation, tended to be quickest in the second period; as for rotation, the degree of rotation tended to be smaller in the third period compared to that in the first.

6) From the result of the present research, it is presu med that the mandibular condyle first moves, featuring rotation, to a comparatively fixed position, and later moves, featuring translation, to the position most appropriate for the pronunciation of the $[\mathrm{a}:]$ sound.

\section{文献}

1) Sönstebö, H.R. : C.E. Luce's Recordings of Mandibular Movements. J. Prosth. Dent., 11 : 1068 1073, 1961.

2) McCollum, B. B. : Fundamentals involved in Prescri bing Restorative Dental Remedies, D. Items of Int., $61: 733 \sim 736,852 \sim 863,1939$.

3）中澤 勇: 下效運動/補緅学的研究, 口病誌, 13:81 98, 1939.

4) 松本政雄: 人/咀嚼運動 7 正確二描記スル方法, 口病誌, $14: 73 \sim 84,1940$.

5) Kurth, L.E. : Mandibular Movements in Mastication, J.A.D.A., $29: 1769 \sim 1790,1942$.

6) Jankelson, B. : The physiology of the stomatog. nathic system, J.A.D.A., $46: 375 \sim 386,1953$.

7）兼子尚道：発音における下顎, 口唇, 舌の運動の研究（母 音の部), 音声の研究, $8: 1 \sim 18,1957$.

8）西連寺永康, 柳沢定勝: 頭部体軸方向レントゲン規格撮 影法について，歯科月報，32:16〜19，1957.

9）佐久間孔毅：マルチフラッシュ装㯰による有歯滪の前後 および開䦥運動の研究, 口病誌, $26: 1511 \sim 1536,1958$.

10) Ulrich, J. : The Human Temporomandibular Joint : Kinematics and Actions of the Masticatory Muscles, J. Prosth. Dent., $9: 399 \sim 406,1959$.

16）加藤吉昭：ストロボ撮影法による下䪽運動, 殊に補縱学 的見地からみた運動に関する研究, 日大医誌，19： $1451 \sim 1487,1960$.

12）末次恒夫：マルチフラッシュ装圆による無荬影の前後,

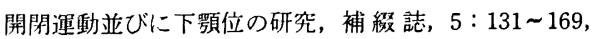
1961.

13）竹花 一：ストロボ撮影法による総義歯患者の顆路およ び切歯路に関する研究，歯科月報, $36: 501 \sim 534,1962$.

14）大石司郎：アーム型運動分解器とコンデンサー法による 下顎運動の研究, 第 1 報 測定装㯰について, 口病誌, $29: 164 \sim 180,1962$.

15）三谷春保, 山下 敦, 川畑 衛, 戸田外穂, 小川晴彦：
電気的下顎運動記録の一新法, 歯科医学, $26: 415 \sim 420$, 1963.

16) Aull, A.E. : Condylar Determinants of Occlusal Patterns, J. Prosth. Dent., 15 : 826 846, 1965.

17) Messerman, T. : A means for studying mandibular movements, J. Prosth. Dent., $17: 36 \sim 43,1967$.

18）河野正司：下䪽の矢状面内運動に対応する顆頭運動の研 究, 第 1 報 断層X線規格写真による観察, 補緅誌, $12: 337 \sim 349,1968$.

19）河野正司：下顎の矢状面内運動に対応する顆頭運動の研 究, 第二報 マルチフラッシュ装圆による矢状面運動軸 の解析, 補緅誌, $12: 350 \sim 380,1968$.

20) Lee, R.L. : Jaw movements engraved in solid plastic for articulator controls. Part 1. Recording apparatus, J. Prosth. Dent., 22 : 209 224, 1969.

21) Knap, F.J., Richardson, B.L. and Bogstad, J. : A Study of Mandibular Motion in Six Degrees of Freedom, J.D. Res., $49: 289 \sim 292,1970$.

22）坂東永一：下䅡位のテレメータリングによる経時的観 察, 補緅誌, $14: 183 \sim 203,1970$.

23）古屋紀一：X線映画法による発音時の下䫒位に関する研 究, 補緅誌, $15: 221 \sim 238,1971$.

24) Jankelson, B., Swain, C.W., Crane, P.F., Radke, J.C. : Kinesiometric instrumentation : a new technology, J.A.D.A., $90: 834 \sim 840,1975$.

25）太田勝美：口外記録法による顎関節顆頭運動の分析, 第 1 報, 口病誌, $42: 192 \sim 201,1975$.

26）三浦不二夫, 近藤勝義 : XY-tracker を利用した新しい 䫑連動記録装置について, 口病誌, $43: 177 \sim 183,1976$.

27）野村修一, 平野秀利, 木竜微, 石岡 靖, 斉藤義明 : 非接触型下顎運動測定装置の試作, 補 释誌, $21: 511$ 519, 1977.

28）坂東永一, 栗山 實, 河野正司, 中野雅徳, 長谷川成 男 : 写真撮影による下䫟運動測定法, 補緅誌, $23: 677$ $690,1979$.

29）丸山剛郎, 西尾公一, 古屋昌昭, 藤井康伯, 宮内修平, 下総高次：下颚位が習慣的下䫑開閉運動経路に及ぼす影 響に関寸る研究, 補緅誌, $26: 30 \sim 35,1982$.

30) Hickey, J.C., Allison, M.L., Woelfel, J.B., Boucher, C.O., Stacy, R.W. : Mandibular Movements in Three Dimensiows, J. Prosth. Dent., 13:72 92, 1963.

31）石原寿郎, 河村洋二郎：臨床家のためのオクルージョ ン, 石原咬合論, 医歯薬出版, 東京, 1978.

32）福島俊士：習慣的開閉運動における顆頭運動の研究，補 綴誌， $15: 267 \sim 290,1971$.

33）舟久保太, 根本一男 : 半調節性咬合器の運動経路に関す る理論的研究, 補緅誌, $25: 259 \sim 274,1981$. 
34）真柳昭紘：側方滑走運動における顆頭運動に関する研 究, 補緅誌, $14: 158 \sim 182,1970$.

35）揫田克躬：日本語音の構音に関する研究, 第三報 母音 の構音姿勢の「レントゲン」撮影的研究 その 1 ， 口病 誌, $11: 410 \sim 425,1937$.

36）日比野勉：日本語構音に関する「レ」線的研究第二篇正 常人の構音時に於ける発声器官並に所謂附属管腔の系統 的観察, 阪大歯誌, 1-2:203 215, 1956.

37）関根 弘：調音時の下顎運動に関寸る研究，第 2 報 日 本語調音時の下䫟運動について，歯科学報，59：1265 1274, 1959.

38) Pound, E. : The Mandibular Movements of Speech and Their Seven Related Values, J. Prosth. Dent., $16: 835 \sim 843,1966$.

39）三谷 卓: 両唇音と歯音ならびに母音発声時の下顎切歯 点矢状面運動について, 歯科医学, 30:1081 1116,
1967.

40) Murrell, G.A. : Phonetics, function, and anterior occlusion, J. Prosth. Dent., 32:23 31, 1974.

41）立岩達治：前歯部被蓋度と発音との関係, 補緅誌, 22 : $113 \sim 134,1978$.

42）田中 収：日本語 $\mathrm{S}$ 発音洔の下頻運動に関寸る研究, 補 緅誌， $24 ： 628 \sim 646,1980$.

43）長島信也, 小泉政幸, 富田 豊, 石塚 亨, 羽田京太郎, 栈 淑行, 服部嘉郎, 工藤忠男, 中澤 靖: マルチスト ロボ装置を応用した下頡運動の研究, 第 1 報 マルチス トロボ装置について, 補緅誌, $26: 943 \sim 947,1982$.

44）谷 正明：オプティカルグラスファイバー点光源掫影法 による側方運動の研究, 日大口腔科学, 8:187 206, 1982.

45）河村洋二郎：口腔生理学, 339 367, 永末書店, 京都, 1982. 